\title{
Seasonality in Particulates Distribution from Dumpsites in the Niger Delta Region of Nigeria: A Health Risk Assessment Approach
}

\author{
Glory Richard $^{1 *}$, Moses O. Nwagbara ${ }^{2}$, Vincent E. Weli ${ }^{3}$ \\ ${ }^{I}$ Department of Community Medicine, Faculty of Clinical Sciences, Niger Delta University, Wilberforce Island, \\ Bayelsa State, Nigeria. \\ ${ }^{2}$ Department of Soil Science and Meteorology, Michael Okpara University of Agriculture, Umudike, Abia State, \\ Nigeria. \\ ${ }^{3}$ Department of Geography and Environmental Management, University of Port Harcourt, Choba, Port \\ Harcourt, Rivers State, Nigeria.
}

*Corresponding Author: Glory Richard, Department of Community Medicine, Faculty of Clinical Sciences, Niger Delta University, Wilberforce Island, Bayelsa State, Nigeria.

\begin{abstract}
This study evaluated seasonality in particulates distribution from waste dump sites in some selected Niger Delta states. The particulates (PM1, PM 2.5, PM 4, PM 7, PM 10, and TSP) were determined at 3 distances (3.05 meter, 7.62 meter and 15.24 meter) for 6 months covering the predominant seasons (wet and dry) Delta, Bayelsa, Rivers and Abia states. The particulates were measured with mini-volume air sampler and the health risk was carried out following standard protocol. The health risk assessment was carried under two background scenarios (median and geometric mean). Results for PM1, PM2.5, PM4, PM7, PM10, TSP ranged from $16.43-24.71 \mu \mathrm{g} / \mathrm{m3}, 26.44-40.10 \mu \mathrm{g} / \mathrm{m3}, 41.64-61.53 \mu \mathrm{g} / \mathrm{m3}, 62.37-98.54$ $\mu \mathrm{g} / \mathrm{m} 3,81.63-141.51 \mu \mathrm{g} / \mathrm{m3}, 110.20-270.91 \mu \mathrm{g} / \mathrm{m3}$, respectively. Analysis of variance showed that there were significant variations at $p<0.05$ across the distances, locations and months of study and their interactions. In addition, the particulates showed significant relationship with each other at $p<0.01$. The particulates were higher during the dry season compared to wet season, suggesting the influence of climate/weather condition. Health risk assessment showed that particulates were within slight pollution $(50<H R A \leq 100)$ to Hazardous $(200<H R A \leq 250)$. The health risk assessment under both background scenarios showed slight variations. The health assessment suggests that sensitive group could be at risk of diseases associated with particulates in the study area over a prolong period of time. As such, there is need to use most suitable approach in waste management in the study area.
\end{abstract}

Keywords: Environmental pollution, Nigeria, Particulates, Pubic health, Weather

\section{INTRODUCTION}

Seasonality in the Niger Delta is a function of two main seasons, dry and wet periods, with rainfalls beginning from April to October with intermittent break often referred to as: August break and dry season from November terminating in March of the following year. In August, there is a decline in amount of rainfall often referred to as little dry season i.e end of July to beginning of August (Adejuwon and Odekunle, 2006). In recent times, it appears that rainfall pattern is beginning to shift from the conventional known time. For instance, Adejuwon (2011) studied seasonal patterns in the Niger Delta between 1931 and 1997 and reported that raining season begins from February/March to November and dry season from December to January/February. This variation could be associated to difference in rainfall determinant factors linked to inter-tropical discontinuity (Adejuwon, 2011). The patterns, distribution and total amount of rainfall are important aspects of the Niger Delta climate. According to Omogbai (2010), the factors that enhance or inhibit rainfall precipitation in West Africa and Nigeria in particular is the progression or regression of the zone of influence of the tropical maritime air mass and related discontinuity zone. Several human activities often cause air pollution. But in developing country like Nigeria most of the activities are seldom monitored apart from oil and gas sector and few other manufacturing/ production facilities. Many of these manufacturing sectors generate wastes some of which are treated before discharge into the environment. However, the 
municipal wastes are often not treated. In many coastal regions in the Niger Delta these wastes are combusted in dump site during the dry season releasing particulates and other pollutant gases into the environment. This process is influenced by the prevailing weather condition. In the wet season, the process of decomposition is pronounced across dumpsites, releasing highly offensive odor to the atmosphere.

Several studies have been carried out on particulates from some sectors in Nigeria. For instance, Ediagbonya et al. (2012) studied the level of inhalable and respirabletotal suspended particulates (TSP) fractions in rural and urban centers of Niger Delta and reported higher fractions of inhalable and respirable TSP in urban centers compared to rural centers. Dimari et al. (2008) studied the pollution synergy from the concurrence of the harmattan, fugitive dust and combustion emissions in Maiduguri metropolis and reported that particulate matter deposition rates, sulphate and heavy metal (As, $\mathrm{Cd}, \mathrm{Cr}$, $\mathrm{Cu}, \mathrm{Fe}, \mathrm{Ni}$ and $\mathrm{Pb}$ ) concentrations were higher in traffic area. Owoade et al. (2012) studied the correlation between particulate matter concentrations and meteorological indicators (wind speed, wind direction, air temperature, rainfall, relative humidity and global radiation) at a work site in Ile-Ife and reported that temperature did not significantly influence particulate matter concentration, but correlates with wind speed and direction. The authors further reported higher concentrations of particulates during the dry season compared to wet season, suggesting seasonal influence.

Efe (2008) studied the spatial distribution of particulate air pollution in Nigerian cities and reported that $70 \%$ of Nigerian urban cities are sites with a high rate of daily mean/annual mean ambient PM10 of over $120 \mu \mathrm{g} / \mathrm{m} 3$, while $<30 \%$ of Nigerian urban centres had mean annual ambient PM10 value of $119.2 \mu \mathrm{g} / \mathrm{m} 3$. Orogade et al. (2016) studied source apportionment of fine and coarse particulate matter in industrial areas of Kaduna and reported values exceeding the Nigerian Annual National Ambient Air Quality Standard (NAAQS) of $15 \mu \mathrm{gm}-3$ for PM2.5 and $60 \mu \mathrm{gm}-3$ for PM10. Weli (2014) studied atmospheric concentration of particulate pollutants and its implications for respiratory health hazard management in Port Harcourt metropolis and reported that industrial area and high density residential areas has the higher value of PM10 compared to the transportation sector. The author further suggested that risk of respiratory related diseases is expected to be higher among high density residential and industrial areas. Ladan (2013) reviewed air pollution and control measures in Nigeria and reported that it is difficult to achieve cooperation for air pollution control in developing countries like Nigeria whose main concern is to provide for the basic needs of food, shelter and employment for her populace. Ngele and Onwu (2015) studied ambient air particulate matter levels in selected urban centres of Niger Delta region and reported that the TSP levels in Uyo and Port Harcourt were relatively higher than those of the other three cities monitored. The authors further stated that the TSP levels were within the guideline limit while levels of PM10 and PM2.5 either exceeded or were very close to the guideline limits in all the cities monitored and hence presents possible public health risk. Ohimainet al.(2013) reported high concentration of TSP in oil palm processing plant in Elele, River state which decreased as the distance from the emission station increased.

Therefore, this study was aimed at assessing the seasonality in particulates distribution from selected dumpsites in the Niger Delta region of Nigeria using a health risk assessment model.

\section{Materials AND Methods}

\subsection{Study Area}

The Niger Delta is a home to about 20 million people and 40 different ethnic groups, this floodplain makes up 7.5\% of Nigeria's total land mass (Donwaet al., 2015). Similarly, Oshwofasaet al. (2012) reported that Niger Delta region has 12 major ethnic groups, 800 communities and population of about 30 million. This study was carried out in four states in the Niger Delta (including Delta, Bayelsa, Rivers and Abia) around waste dumpsite. Waste dumpsites were studied in government approved central dumpsite along Amassoma-Yenagoa road, Bayelsa state, in AgbharaOtor in Delta state, Elele in Rivers state, and Aba in Abia state, Nigeria. In the study area many wastes receptacles are close economic areas including garage/ motor parks, markets, busy express way. Two predominant seasons including dry (November to March of the preceding year) and wet season (April to October) is identified in the area. The wet season is characterized by lower temperature and higher relative humidity as compared to dry season with higher temperature and lower relative humidity. In general, 
the relative humidity and temperature of the area is $50-95 \%$ and $28 \pm 8{ }^{\circ} \mathrm{C}$ respectively all year round (Izah et al., 2017a).

\subsection{Sample Measurement}

The particulate matter :(PM1, PM2.5, PM4, PM7, PM10) and TSP was measured using a mini-volume air sampler (model: AEROCET 531, Manufactured by Met-one instrument, USA) with a pre-weighed membrane filter $(45 \mu \mathrm{m})$ to collect particulate matter. Measurement were carried in triplicates $(3.05 \mathrm{~m}$, $7.62 \mathrm{~m}$ and $15.24 \mathrm{~m}$ ) in some Niger Delta states (Bayelsai.e location A, Rivers i.e. location B, Delta i.e. Location C, and Abiai.e Location D) in dry season (November, January and March) and wet season (May, July and September).

\subsection{Techniques of Data Analysis}

SPSS software version 20 was used to carry out the statistical analysis. The particulates (PM10, PM7, PM4, PM2.5, PM1, TSP) were presented as mean for locations, distances and months. Three-way analysis of variance was carried out at $\alpha=0.05$, and Duncan multiple range test statistics was used to discern the source of variations between means. Spearman rho correlation was used to show significant relationship between the various particulate sizes.

\subsection{Health Risk Assessment}

Geometric and median mean have been widely used in assessing environmental risk of toxicant in the environment (Izahet al., 2017a-c, 2018; Bhutianiet al., 2017). This was adopted in this study. The air quality index was calculated based on the formula of Angayeet al. (2018), ACT Government (2018) with slight modification. The modification of the universal air quality index was made by replacing National Regulatory Limit for individual air particulates using background values (median and geometric mean).

$$
\text { Air Quality Index }=\frac{\text { Volume of individual air emission (V) }}{\text { Refernece Background value (RBV) }} \times 100
$$

Information on air quality criteria in Nigeria is scanty; hence theindex previously applied by Akinfolarinet al. (2017) was slightly modified, based on the air quality index criteria of some other countries including China, India, South Korea and Singapore. The health risk index for classification were; HRA $\leq 50$ (no pollution), $50<\mathrm{HRA} \leq 100$ (Slight pollution), $100<\mathrm{HRA} \leq 150$ (moderate pollution), $150<$ HRA $\leq 200$ (Significant/Dense pollution), 200<HRA $\leq 250$ (Hazardous), HRA $>250$ (Very Hazardous). The no pollution is an indication of no impact on human health over a prolong period of time; the slight pollution is an indication of impacts on individuals expose to some health risk especially among immunocompromised patients over a long period of time; the moderate pollution is an indication of impacts on individuals expose to some health risk especially among immune compromised patients (including infants, children and elderly) over a short period of time; significant pollution indicates impacts arising from respiratory response (asthma, lungs etc) especially in infants, children, elderly (>70 years) and other immune-compromised individuals; hazardous pollution is an indication of high response including itching of the eye, respiratory condition among individuals (including infants, children, adolescent, adult and elderly) exposed to the pollutant over a period $>6$ hours; and very hazardous is an indication of response such as itching of the eye, respiratory condition among individuals (including infants, children, adolescent, adult and elderly) exposed to the pollutant over a period $<6$ hours depending on the type of pollutant.

\section{RESULTS AND DISCUSSION}

The concentration of particulate matter $1\left(\mathrm{PM}_{1}\right)$ in the months studied in a dumpsite ranged from 13.87 $-16.62 \mu \mathrm{g} / \mathrm{m}^{3}$, being significantly different at $\mathrm{p}<0.05$ (Table 1 ). The spatial-temporal distribution differs significantly at $\mathrm{p}<0.05$ ranging from $13.55-18.83 \mu \mathrm{g} / \mathrm{m}^{3}$ (Table 2). The concentration based on distances ranged from $12.34-18.94 \mu \mathrm{g} / \mathrm{m}^{3}$. The concentration gradient showed significant decrease at $\mathrm{p}<0.05$ ) as distances from the emission source increased (Table 3). The interactions of $\mathrm{PM}_{1}$ on distances, months and locations revealed significant variation at $\mathrm{p}<0.05$ (Table 4 ).

Particulate matter $2.5\left(\mathrm{PM}_{25}\right)$ concentration in the months of studied at a dumpsite ranged from 27.28 $25.96 \mu \mathrm{g} / \mathrm{m}^{3}$. There was significant variations at $\mathrm{p}<0.05$ among the various months studied (Table 1 ). The spatial-temporal distribution ranged from $21.84-30.67 \mu \mathrm{g} / \mathrm{m}^{3}$ (Table 2). The concentration 
ofPM 2.5 based on distances ranged from $20.17-30.26 \mu \mathrm{g} / \mathrm{m}^{3}$ and showed significant decrease at $\mathrm{p}<0.05$ as distances from the emission source increased (Table 3). $\mathrm{PM}_{2.5}$ interactions on distances, months and locations show significant difference sat $\mathrm{p}<0.05$ (Table 4 ).

A study of the concentration of particulate matter $4\left(\mathrm{PM}_{4}\right)$ across dump sites in the months considered ranged from $33.16-39.33 \mu \mathrm{g} / \mathrm{m}^{3}$. There was significant difference at $\mathrm{p}<0.05$ across the months studied (Table 1). The spatial-temporal distribution of $\mathrm{PM}_{4}$ ranged from $30.47-48.80 \mu \mathrm{g} / \mathrm{m}^{3}$ (Table 2). Based on distance the concentration of $\mathrm{PM}_{4}$ ranged from $27.59-47.62 \mu \mathrm{g} / \mathrm{m}^{3}$. It showed significant decline at $\mathrm{p}<0.05$ as distance away from the emission source increased (Table 3). The interactions of $\mathrm{PM}_{4}$ on distances, months and locations showed a significant variation at $\mathrm{p}<0.05$ (Table 4).

Particulate matter $7\left(\mathrm{PM}_{7}\right)$ concentrations in the months of study at a dumpsite ranged from 48.22 $64.15 \mu \mathrm{g} / \mathrm{m}^{3}$. There was significant difference at $\mathrm{p}<0.05$ among the various months (Table 1 ). The spatial-temporal distribution of $\mathrm{PM}_{7}$ across dumpsites ranged from $45.55-76.89 \mu \mathrm{g} / \mathrm{m}^{3}$ (Table 2). Based on distance the concentration of $\mathrm{PM}_{7}$ ranged from $42.74-74.65 \mu \mathrm{g} / \mathrm{m}^{3}$. It showed significant decline at $\mathrm{p}<0.05$ as distance from dumpsite increased (Table 3 ). The interactions of $\mathrm{PM}_{7}$ on distances, months and locations showed significant variations at $\mathrm{p}<0.05$ (Table 4).

Particulate matter $10\left(\mathrm{PM}_{10}\right)$ concentration of a dumpsite in the months of study ranged from 61.09 $82.12 \mu \mathrm{g} / \mathrm{m}^{3}$. There was significant difference at $\mathrm{p}<0.05$ among the various months studied (Table 1 ). The spatial-temporal distribution of $\mathrm{PM}_{10}$ in the dumpsite ranged from $58.20-107.34 \mu \mathrm{g} / \mathrm{m}^{3}$ (Table 2). The concentration ranged from $54.92-101.43 \mu \mathrm{g} / \mathrm{m}^{3}$ based on distances. The concentration declined as the distances from the emission source increased (Table 3). It showed significant interactions at $\mathrm{p}<0.05$ on distances, months and locations (Table 4).

The concentrations of total suspended particulate (TSP) of dumpsites in the various months of study ranged from $78.71-127.30 \mu \mathrm{g} / \mathrm{m}^{3}$, being significantly different at $\mathrm{p}<0.05$ among the months studied (Table 4.1). The spatial-temporal distribution of (TSP) across dumpsites ranged from $73.22-162.77$ $\mu \mathrm{g} / \mathrm{m}^{3}$ (Table 2). The concentration gradient ranged from $69.26-147.11 \mu \mathrm{g} / \mathrm{m}^{3}$ based on distances and significantly declined at $p<0.05$ as the distances from the emission source increased (Table 4). Total suspended particulate showed significant interactions at $\mathrm{p}<0.05$ on distances, months and locations (Table 4).

Table1. Bimonthly distribution of particulates from waste dumpsite in some Niger Delta States

\begin{tabular}{|c|c|c|c|c|c|c|}
\hline \multirow{2}{*}{ Parameters } & \multicolumn{6}{|l|}{ Months } \\
\hline & Nov & Jan & Mar & May & July & Sept \\
\hline PM $1, \mu \mathrm{g} / \mathrm{m}^{3}$ & $16.62 \mathrm{~d}$ & $17.22 \mathrm{e}$ & $13.87 \mathrm{a}$ & $15.11 \mathrm{c}$ & $15.16 \mathrm{c}$ & $14.68 \mathrm{~b}$ \\
\hline PM $2.5, \mu \mathrm{g} / \mathrm{m}^{3}$ & $25.96 \mathrm{~d}$ & $27.28 \mathrm{e}$ & $22.79 \mathrm{a}$ & $24.09 \mathrm{bc}$ & $24.47 \mathrm{c}$ & $23.93 \mathrm{~b}$ \\
\hline $\mathrm{PM} 4, \mu \mathrm{g} / \mathrm{m}^{3}$ & $39.33 d$ & $41.29 \mathrm{e}$ & $33.16 \mathrm{a}$ & $36.09 \mathrm{bc}$ & $36.73 \mathrm{c}$ & $35.21 \mathrm{~b}$ \\
\hline PM $7, \mu \mathrm{g} / \mathrm{m}^{3}$ & $59.22 \mathrm{~d}$ & $64.15 \mathrm{e}$ & $48.22 \mathrm{a}$ & $56.39 \mathrm{c}$ & $56.64 \mathrm{c}$ & $52.13 \mathrm{~b}$ \\
\hline PM $10, \mu \mathrm{g} / \mathrm{m}^{3}$ & $78.70 \mathrm{~d}$ & $82.12 \mathrm{e}$ & $61.09 \mathrm{a}$ & $75.49 \mathrm{c}$ & $74.50 \mathrm{c}$ & $67.55 \mathrm{~b}$ \\
\hline $\mathrm{TSP}, \mu \mathrm{g} / \mathrm{m}^{3}$ & $106.55 \mathrm{e}$ & $127.30 \mathrm{f}$ & $78.71 \mathrm{a}$ & $101.23 \mathrm{~d}$ & $95.62 \mathrm{c}$ & $88.91 \mathrm{~b}$ \\
\hline
\end{tabular}

Means (36) with Different letters across the row indicate significant difference at $p<0.05$ according to Duncan multiple range test statistics

Table2. Spatial distribution of particulates from waste dumpsite in some Niger Delta States

\begin{tabular}{|l|l|l|l|l|}
\hline \multirow{2}{*}{ Parameters } & \multicolumn{4}{|c|}{ Locations } \\
\cline { 2 - 5 } & A & B & C & D \\
\hline PM $1, \mu \mathrm{g} / \mathrm{m}^{3}$ & $18.83 \mathrm{~d}$ & $14.93 \mathrm{c}$ & $13.55 \mathrm{a}$ & $14.47 \mathrm{~b}$ \\
\hline PM $2.5, \mu \mathrm{g} / \mathrm{m}^{3}$ & $30.67 \mathrm{~d}$ & $23.57 \mathrm{c}$ & $21.84 \mathrm{a}$ & $22.94 \mathrm{~b}$ \\
\hline PM $4, \mu \mathrm{g} / \mathrm{m}^{3}$ & $48.80 \mathrm{~d}$ & $34.99 \mathrm{c}$ & $30.47 \mathrm{a}$ & $33.61 \mathrm{~b}$ \\
\hline PM $7, \mu \mathrm{g} / \mathrm{m}^{3}$ & $76.89 \mathrm{~d}$ & $52.15 \mathrm{c}$ & $45.55 \mathrm{a}$ & $49.91 \mathrm{~b}$ \\
\hline PM $10, \mu \mathrm{g} / \mathrm{m}^{3}$ & $107.34 \mathrm{~d}$ & $64.94 \mathrm{c}$ & $58.20 \mathrm{a}$ & $62.49 \mathrm{~b}$ \\
\hline TSP $\mu \mathrm{g} / \mathrm{m}^{3}$ & $162.77 \mathrm{~d}$ & $83.37 \mathrm{c}$ & $73.22 \mathrm{a}$ & $79.51 \mathrm{~b}$ \\
\hline
\end{tabular}

Means (54) with Different letters across the row indicate significant difference at $\mathrm{p}<0.05$ according to Duncan multiple range test statistics 
Seasonality in Particulates Distribution from Dumpsites in the Niger Delta Region of Nigeria: A Health Risk Assessment Approach

Table3. Distance distribution of particulates from waste dumpsite in some Niger Delta States

\begin{tabular}{|l|l|l|l|}
\hline \multirow{2}{*}{ Parameters } & Distance, meter & \multicolumn{2}{l|}{} \\
\cline { 2 - 4 } & 3.05 & 7.62 & 15.24 \\
\hline PM $1, \mu \mathrm{g} / \mathrm{m}^{3}$ & $18.94 \mathrm{c}$ & $15.05 \mathrm{~b}$ & $12.34 \mathrm{a}$ \\
\hline PM $2.5, \mu \mathrm{g} / \mathrm{m}^{3}$ & $30.26 \mathrm{c}$ & $23.84 \mathrm{~b}$ & $20.17 \mathrm{a}$ \\
\hline PM $4, \mu \mathrm{g} / \mathrm{m}^{3}$ & $47.62 \mathrm{c}$ & $35.70 \mathrm{~b}$ & $27.59 \mathrm{a}$ \\
\hline PM $7, \mu \mathrm{g} / \mathrm{m}^{3}$ & $74.65 \mathrm{c}$ & $50.98 \mathrm{~b}$ & $42.74 \mathrm{a}$ \\
\hline PM $10, \mu \mathrm{g} / \mathrm{m}^{3}$ & $101.43 \mathrm{c}$ & $63.38 \mathrm{~b}$ & $54.92 \mathrm{a}$ \\
\hline TSP,$\mu \mathrm{g} / \mathrm{m}^{3}$ & $147.11 \mathrm{c}$ & $82.78 \mathrm{~b}$ & $69.26 \mathrm{a}$ \\
\hline
\end{tabular}

Means (72) with Different letters across the row indicate significant difference at $\mathrm{p}<0.05$ according to Duncan multiple range test statistics

Table4. P-values of particulates from waste dumpsite in some Niger Delta States

\begin{tabular}{|c|c|c|c|c|c|c|c|}
\hline Parameters & Months & Locations & Distances & $\begin{array}{l}\text { Interaction of } \\
\text { months and } \\
\text { location }\end{array}$ & $\begin{array}{l}\text { Interaction } \\
\text { of months } \\
\text { and distance }\end{array}$ & $\begin{array}{l}\text { Interaction } \\
\text { of distance } \\
\text { and } \\
\text { location }\end{array}$ & $\begin{array}{l}\text { Interaction } \\
\text { of months, } \\
\text { locations } \\
\text { and } \\
\text { distance }\end{array}$ \\
\hline $\begin{array}{l}\text { PM } 1, \\
\mu \mathrm{g} / \mathrm{m}^{3}\end{array}$ & 0.000 & 0.000 & 0.000 & 0.000 & 0.000 & 0.000 & 0.000 \\
\hline $\begin{array}{l}\mathrm{PM} \\
\mu \mathrm{g} / \mathrm{m}^{3}\end{array}$ & 0.000 & 0.000 & 0.000 & 0.000 & 0.000 & 0.019 & 0.000 \\
\hline $\begin{array}{l}\text { PM } \\
\mu \mathrm{g} / \mathrm{m}^{3}\end{array}$ & 0.000 & 0.000 & 0.000 & 0.000 & 0.000 & 0.000 & 0.000 \\
\hline $\begin{array}{l}\mathrm{PM} \\
\mu \mathrm{g} / \mathrm{m}^{3}\end{array}$ & 0.000 & 0.000 & 0.000 & 0.000 & 0.000 & 0.000 & 0.000 \\
\hline $\begin{array}{l}\mathrm{PM} \quad 10, \\
\mu \mathrm{g} / \mathrm{m}^{3}\end{array}$ & 0.000 & 0.000 & 0.000 & 0.000 & 0.000 & 0.000 & 0.000 \\
\hline $\begin{array}{l}\text { TSP, } \\
\mu \mathrm{g} / \mathrm{m}^{3}\end{array}$ & 0.000 & 0.000 & 0.000 & 0.000 & 0.000 & 0.000 & 0.000 \\
\hline
\end{tabular}

In this study there was significant variations at $\mathrm{p}<0.05$ between locations, distances and months. Particulate matters were higher during the dry season compared to the wet season. This could be associated to seasonal influence, thus lower values during the wet season is due to sequestrations of particulate matter by moisture content due to high level of relative humidity (Angaye and Abowei, 2018). Furthermore, high temperature (characterized by dust and wind) during the dry season enhance the mobility of particulates as reported by (Ohimain et al., 2013; Ohimain and Izah, 2013). Rim-Rukeh (2014) reported that high particulates during the dry season could be associated to suspended smoke that originated from dumpsites due to uncontrolled open air burning of municipal solid wastes.

Significant difference at $\mathrm{p}<0.05$ suggest the effects of varying level of anthropogenic activities among the various sampling locations, distances and months. PM 1 and 2.5 are widely reported as fine particulates while PM 4 and above are referred to as coarse particulates. Fine particulates are highly detrimental to human health because they have the potential to be absorbed by the alveoli in the respiratory system where they could cause discomfort. Nigerian ambient air quality only specified limits for total suspended particulate. The values were higher than the daily average of $250 \mu \mathrm{g} / \mathrm{m} 3$ for waste dumpsite and lower than 1-hour value of $600 \mu \mathrm{g} / \mathrm{m} 3$ as reported by FEPA (1991). The trend of particles reported in this study is comparable to the work of Angaye and Abowei (2018) that reported particulates in dry and wet seasons in the range of $17.04-32.81 \mu \mathrm{g} / \mathrm{m} 3$ and $14.03-19.03 \mu \mathrm{g} / \mathrm{m} 3$ (PM1), $23.11-44.87$ and20.41 - 32.07 $\mu \mathrm{g} / \mathrm{m} 3$ (PM2.5), $32.03-62.80$ and $29.82-50.54 \mu \mathrm{g} / \mathrm{m} 3$ (PM4), 75.01- 197.11 and $45.17-71.27 \mu \mathrm{g} / \mathrm{m} 3$ (PM7), $109.40-305.10$ and $56.53-93.07$ $\mu \mathrm{g} / \mathrm{m} 3(\mathrm{PM} 10)$ and $227.66-597.26 \mu \mathrm{g} / \mathrm{m} 3$ and $72.40-172.23 \mu \mathrm{g} / \mathrm{m} 3$ (TSP)respectively. Rim-Rukeh (2014) reported PM10 from waste dumpsite in Delta state in the range of $773-801 \mu \mathrm{g} / \mathrm{m} 3$. Ezekweet al. (2016) reported particulates from dumpsites in Port-Harcourt as $25.50-58.26 \mu \mathrm{g} / \mathrm{m} 3$ (PM0.3), 1.61 - $8.48 \mu \mathrm{g} / \mathrm{m} 3$ (PM0.5), 0.35 - $0.66 \mu \mathrm{g} / \mathrm{m} 3$ (PM1.0), $0.16-1.31 \mu \mathrm{g} / \mathrm{m} 3$ (PM2.0) and $2.61-11.96$ $\mu \mathrm{g} / \mathrm{m} 3$ (PM5.0). Ubouhand Nwawike (2016) also reported PM10 at waste dumpsite in Nekede, Imo State in the range of $6.30-6.80$ (in the morning) and 6.00-6.40 ppm (in the evening). 
Seasonality in Particulates Distribution from Dumpsites in the Niger Delta Region of Nigeria: A Health Risk Assessment Approach

The health risk assessment of the particulate matter is presented in Table 5. The health risks ranges from no pollution $(H R A \leq 50)$ to moderate pollution $(100<H R A \leq 150)$ except for few instances like PM7 in which location D was hazardous under geometric mean consideration in wet season, PM10 in location A was densely polluted under median mean consideration in dry season, and total suspended particulates in location A was hazardous under median mean consideration in dry season. Since extreme health risk occurred in only one of the background scenarios, it could not be considered as true impact but chance occurrence.

Typically, the various particulates (PM1, PM 2.5, PM 4, PM 7, PM 10, TSP) show varying degree of toxicity to humans. For instances, PM1 and PM2.5 are often regarded as fine particulates because they have the tendency to pass through the alveoli and cause problems in the respiratory tracts. While PM4 to PM10 is regarded as coarse particulates because they do not easily penetrate into the bronchi. However, the values reported in this study suggest moderate contamination when compared to the Federal ministry of environment limit of $250 \mu \mathrm{g} / \mathrm{m} 3$.

Table5. Air quality index of particulates from wastes dumpsite in some states in the Niger Delta

\begin{tabular}{|c|c|c|c|c|c|c|c|c|c|c|c|c|c|}
\hline \multirow{2}{*}{$\begin{array}{l}\text { Location } \\
\mathrm{S}\end{array}$} & \multirow{2}{*}{$\begin{array}{l}\text { Mean } \\
\text { consid } \\
\text { eration }\end{array}$} & \multicolumn{2}{|l|}{$\mathrm{PM}_{1}$} & \multicolumn{2}{|c|}{$\mathrm{PM}_{2.5}$} & \multicolumn{2}{|l|}{$\mathrm{PM}_{4}$} & \multicolumn{2}{|c|}{$\mathrm{PM}_{7}$} & \multicolumn{2}{|c|}{$\mathrm{PM}_{10}$} & \multicolumn{2}{|l|}{ TSP } \\
\hline & & Dry & Wet & Dry & Wet & Dry & Wet & Dry & Wet & Dry & Wet & Dry & Wet \\
\hline \multirow[t]{2}{*}{$\bar{A}$} & $\begin{array}{l}\text { Geom } \\
\text { etric }\end{array}$ & $\begin{array}{l}125.5 \\
6\end{array}$ & $\begin{array}{c}112 \\
39\end{array}$ & $\begin{array}{l}129 . \\
35\end{array}$ & $\begin{array}{l}113 . \\
74\end{array}$ & $\begin{array}{l}126 . \\
29\end{array}$ & $\begin{array}{l}113 . \\
91\end{array}$ & $\begin{array}{c}128 \\
71\end{array}$ & $\begin{array}{l}108 . \\
62\end{array}$ & $\begin{array}{l}141 . \\
74\end{array}$ & $\begin{array}{c}138 \\
16\end{array}$ & $\begin{array}{l}186.7 \\
8\end{array}$ & $\begin{array}{c}141 \\
92\end{array}$ \\
\hline & $\begin{array}{l}\text { Media } \\
\mathrm{n}\end{array}$ & $\begin{array}{l}133.2 \\
8\end{array}$ & $\begin{array}{l}113 \\
.69\end{array}$ & $\begin{array}{l}138 . \\
71\end{array}$ & $\begin{array}{l}115 . \\
69\end{array}$ & $\begin{array}{l}133 . \\
94\end{array}$ & $\begin{array}{l}115 . \\
13\end{array}$ & $\begin{array}{l}134 \\
.23\end{array}$ & $\begin{array}{l}105 . \\
68\end{array}$ & $\begin{array}{l}155 . \\
47\end{array}$ & $\begin{array}{l}147 \\
.58\end{array}$ & $\begin{array}{l}224.4 \\
2\end{array}$ & $\begin{array}{l}152 \\
.59\end{array}$ \\
\hline \multirow[t]{2}{*}{$\mathrm{B}$} & $\begin{array}{l}\text { Geom } \\
\text { etric }\end{array}$ & 96.04 & $\begin{array}{l}102 \\
.39\end{array}$ & $\begin{array}{l}94.8 \\
7\end{array}$ & $\begin{array}{l}100 . \\
07\end{array}$ & $\begin{array}{l}96.2 \\
8\end{array}$ & $\begin{array}{l}98.1 \\
7\end{array}$ & $\begin{array}{l}97 . \\
36\end{array}$ & $\begin{array}{l}105 . \\
73\end{array}$ & $\begin{array}{l}92.0 \\
4\end{array}$ & $\begin{array}{l}95 . \\
61\end{array}$ & 84.80 & $\begin{array}{l}98 . \\
38\end{array}$ \\
\hline & $\begin{array}{l}\text { Media } \\
\mathrm{n}\end{array}$ & $\begin{array}{l}101.9 \\
4\end{array}$ & $\begin{array}{l}103 \\
.66\end{array}$ & $\begin{array}{l}101 . \\
73\end{array}$ & $\begin{array}{l}101 . \\
79\end{array}$ & $\begin{array}{l}102 . \\
11\end{array}$ & $\begin{array}{l}99.6 \\
0\end{array}$ & $\begin{array}{l}101 \\
.54\end{array}$ & $\begin{array}{l}102 . \\
86\end{array}$ & $\begin{array}{l}100 . \\
97\end{array}$ & $\begin{array}{l}102 \\
.13\end{array}$ & $\begin{array}{l}102.2 \\
3\end{array}$ & $\begin{array}{l}105 \\
.77\end{array}$ \\
\hline \multirow[t]{2}{*}{$\mathrm{C}$} & $\begin{array}{l}\text { Geom } \\
\text { etric }\end{array}$ & 89.79 & $\begin{array}{l}91 . \\
43\end{array}$ & $\begin{array}{l}88.9 \\
6\end{array}$ & $\begin{array}{l}91.0 \\
5\end{array}$ & $\begin{array}{l}99.1 \\
2\end{array}$ & $\begin{array}{l}90.7 \\
6\end{array}$ & $\begin{array}{l}84 . \\
54\end{array}$ & $\begin{array}{l}87.1 \\
9\end{array}$ & $\begin{array}{l}84.9 \\
0\end{array}$ & $\begin{array}{l}82 . \\
62\end{array}$ & 77.54 & $\begin{array}{l}81 . \\
71\end{array}$ \\
\hline & $\begin{array}{l}\text { Media } \\
\mathrm{n}\end{array}$ & 95.31 & $\begin{array}{l}92 . \\
56\end{array}$ & $\begin{array}{l}95.4 \\
0\end{array}$ & $\begin{array}{l}92.6 \\
1\end{array}$ & $\begin{array}{l}94.5 \\
1\end{array}$ & $\begin{array}{l}92.0 \\
8\end{array}$ & $\begin{array}{l}88 . \\
16\end{array}$ & $\begin{array}{l}84.8 \\
2\end{array}$ & $\begin{array}{l}93.3 \\
1\end{array}$ & $\begin{array}{l}88 . \\
26\end{array}$ & 93.86 & $\begin{array}{l}87 . \\
86\end{array}$ \\
\hline \multirow[t]{2}{*}{$\mathrm{D}$} & $\begin{array}{l}\text { Geom } \\
\text { etric }\end{array}$ & 92.33 & $\begin{array}{l}95 . \\
10\end{array}$ & $\begin{array}{l}91.6 \\
1\end{array}$ & $\begin{array}{l}96.5 \\
6\end{array}$ & $\begin{array}{l}92.2 \\
8\end{array}$ & $\begin{array}{l}98.9 \\
3\end{array}$ & $\begin{array}{l}94 . \\
40\end{array}$ & $\begin{array}{l}99.8 \\
6\end{array}$ & $\begin{array}{l}90.2 \\
8\end{array}$ & $\begin{array}{l}91 . \\
62\end{array}$ & 81.09 & $\begin{array}{l}87 . \\
65\end{array}$ \\
\hline & $\begin{array}{l}\text { Media } \\
n\end{array}$ & 98.00 & $\begin{array}{l}96 . \\
28\end{array}$ & $\begin{array}{l}98.2 \\
4\end{array}$ & $\begin{array}{l}98.2 \\
1\end{array}$ & $\begin{array}{l}107 . \\
97\end{array}$ & $\begin{array}{l}100 . \\
38\end{array}$ & $\begin{array}{l}98 . \\
46\end{array}$ & $\begin{array}{l}97.1 \\
4\end{array}$ & $\begin{array}{l}99.0 \\
3\end{array}$ & $\begin{array}{l}97 . \\
87\end{array}$ & 97.76 & $\begin{array}{l}94 . \\
24\end{array}$ \\
\hline
\end{tabular}

$\mathrm{HRA} \leq 50$ (No pollution); $50<\mathrm{HRA} \leq 100$ (Slightly polluted); $100<\mathrm{HRA} \leq 150$ (Moderately polluted); $150<\mathrm{HRA} \leq 200$ (Significantly/Densely polluted); 200<HRA $\leq 250$ (Hazardous); HRA $>250$ (Very Hazardous)

Spearman's rho on particulates in selected dumpsites in the Niger Delta region of Nigeria is presented in Table 6.PM1 showed significant correlation with other particulates such as PM2.5 $(\mathrm{r}=0.971)$, PM4 $(r=0.959)$, PM7 $(r=0.964)$, PM10 $(r=0.953)$, TSP $(r=0.929)$ at $\mathrm{p}<0.01$. PM2.5 showed positive significant relationship with PM4 $(r=0.975)$, PM7 $(r=0.962)$, PM10 $(r=0.948)$ and TSP $(r=$ $0.922)$ at $\mathrm{p}<0.01$. PM4 showed positive relationship with PM7 $(\mathrm{r}=0.964)$, PM10 $(\mathrm{r}=0.958)$ and TSP $(\mathrm{r}=0.932)$ at $\mathrm{p}<0.01$. PM7 showed significant relationship with PM10 $(\mathrm{r}=0.965)$ and TSP $(\mathrm{r}=0.936)$ at $\mathrm{p}<0.01$. PM10 exhibited significant relationship with $\operatorname{TSP}(\mathrm{r}=0.956)$ at $\mathrm{p}<0.01$ (Table 6). All particulates showed positive significant relationship which is an indication of common source and mutually dependence.

Table6. Spearman's rho of particulates in selected dumpsites in the Niger Delta region of Nigeria

\begin{tabular}{|l|r|r|r|r|r|r|}
\hline \multicolumn{1}{|c|}{ Parameters } & PM 1 & PM 2.5 & PM 4 & PM 7 & PM 10 & TSP \\
\hline PM 1 & 1 & & & & & \\
\hline PM 2.5 & $0.971^{* *}$ & 1 & & & & \\
\hline PM 4 & $0.959^{* *}$ & $0.975^{* *}$ & 1 & & & \\
\hline PM 7 & $0.964^{* *}$ & $0.962^{* *}$ & $0.964^{* *}$ & 1 & & \\
\hline PM 10 & $0.953^{* *}$ & $0.948^{* *}$ & $0.958^{* *}$ & $0.965^{* *}$ & & 1 \\
\hline TSP & $0.929^{* *}$ & $0.922^{* *}$ & $0.932^{* *}$ & $0.936^{* *}$ & $0.956^{* *}$ & 1 \\
\hline
\end{tabular}


**. Correlation is significant at the 0.01 level (2-tailed).

*. Correlation is significant at the 0.05 level (2-tailed).

$\mathrm{N}=218$ (months $=6$, Location $=4$, distance $=3$, replicate $=3$ )

Particulates concentration across dumpsites in dry and wet season was in the range of $17.67-24.71$ $\mu \mathrm{g} / \mathrm{m} 3$ and $16.43-20.18 \mu \mathrm{g} / \mathrm{m} 3$, respectively (PM1), $27.58-40.10 \mu \mathrm{g} / \mathrm{m} 3$ and $26.44-33.03 \mu \mathrm{g} / \mathrm{m} 3$ respectively (PM2.5), $43.42-61.53 \mu \mathrm{g} / \mathrm{m} 3$ and $41.64-52.06 \mu \mathrm{g} / \mathrm{m} 3$ respectively (PM4), $64.72-$ $98.54 \mu \mathrm{g} / \mathrm{m} 3$ and $62.37-77.71 \mu \mathrm{g} / \mathrm{m} 3$ respectively (PM7), $84.76-141.51 \mu \mathrm{g} / \mathrm{m} 3$ and $81.63-136.50$ $\mu \mathrm{g} / \mathrm{m} 3$ respectively (PM10), $112.92-270.91 \mu \mathrm{g} / \mathrm{m} 3$ and $110.20-191.39 \mu \mathrm{g} / \mathrm{m} 3$ (TSP)respectively (Table 7).The variations that occur for all the various particulate matter as well as TSP suggests the influence of distances, seasons and locations around waste dumpsites in the study area (Niger Delta of Nigeria). Based on air quality index, the sensitive group of people may be affected adversely by high concentration gradient of particulates depending on duration of exposure.

The pathological effects associated with particulates are enormous and depends on their concentration (Seiyaboh and Izah, 2019). The authors further stated that the severity depends on the exposure rate, physical and chemical content of the particulates as well as its concentration and dispersal rate. This suggests that meteorological indicators such as wind speed play essential role in the dispersion of air pollutants. High concentration could predispose the individuals exposed to emphysema, pneumonia, bronchitis, asthma and respiratory tuberculosis (Ossaiet al., 1999; Efe, 2008; Ohimainet al., 2013; Seiyaboh and Izah, 2019). Findings from this study show that sensitive group in the study area could be at risk if exposed over prolong period.

Table7. Overall of seasonal influence of particulates in the waste dumpsite in the Niger Delta region of Nigeria

\begin{tabular}{|c|c|c|c|c|c|c|c|c|c|c|c|c|}
\hline \multirow[b]{2}{*}{ Parameters } & \multicolumn{6}{|c|}{ Dry season } & \multicolumn{6}{|c|}{ Wet season } \\
\hline & A & B & $\mathrm{C}$ & D & $\begin{array}{l}\text { Geo } \\
\text { mean }\end{array}$ & $\begin{array}{l}\text { Medi } \\
\text { an } \\
\text { mean }\end{array}$ & A & B & $\mathrm{C}$ & D & $\begin{array}{l}\text { Geo } \\
\text { mean }\end{array}$ & $\begin{array}{l}\text { Media } \\
\mathrm{n} \\
\text { mean }\end{array}$ \\
\hline $\begin{array}{ll}\mathrm{PM} & 1, \\
\mu \mathrm{g} / \mathrm{m}^{3}\end{array}$ & 24.71 & 18.9 & 17.67 & 18.17 & 19.68 & 18.54 & 20.18 & 18.4 & $\begin{array}{l}16 . \\
43\end{array}$ & $\begin{array}{l}17 . \\
09\end{array}$ & 17.97 & 17.75 \\
\hline $\begin{array}{ll}\mathrm{PM} & 2.5, \\
\mu \mathrm{g} / \mathrm{m}^{3} & \end{array}$ & 40.1 & 29.41 & 27.58 & 28.4 & 31 & 28.91 & 33.03 & $\begin{array}{l}29.0 \\
6\end{array}$ & $\begin{array}{l}26 . \\
44\end{array}$ & $\begin{array}{l}28 . \\
04\end{array}$ & 29.04 & 28.55 \\
\hline $\begin{array}{ll}\mathrm{PM} & 4, \\
\mu \mathrm{g} / \mathrm{m}^{3}\end{array}$ & 61.53 & 46.91 & 43.42 & 44.96 & 48.72 & 45.94 & 52.06 & $\begin{array}{l}45.0 \\
4\end{array}$ & $\begin{array}{l}41 . \\
64\end{array}$ & $\begin{array}{l}45 . \\
39\end{array}$ & 45.88 & 45.22 \\
\hline $\begin{array}{ll}\mathrm{PM} & 7, \\
\mu \mathrm{g} / \mathrm{m}^{3}\end{array}$ & 98.54 & 74.54 & 64.72 & 72.28 & 76.56 & 73.41 & 77.71 & $\begin{array}{l}75.6 \\
3 \\
\end{array}$ & $\begin{array}{l}62 . \\
37\end{array}$ & $\begin{array}{l}71 . \\
43\end{array}$ & 71.53 & 73.53 \\
\hline $\begin{array}{ll}\mathrm{PM} & 10, \\
\mu \mathrm{g} / \mathrm{m}^{3} & \end{array}$ & $\begin{array}{l}141.5 \\
1\end{array}$ & 91.9 & 84.76 & 90.14 & 99.84 & 91.02 & 136.5 & $\begin{array}{l}94.4 \\
6 \\
\end{array}$ & $\begin{array}{l}81 . \\
63 \\
\end{array}$ & $\begin{array}{l}90 . \\
52\end{array}$ & 98.80 & 92.49 \\
\hline $\mathrm{TSP}, \mu \mathrm{g} / \mathrm{m}^{3}$ & $\begin{array}{l}270.9 \\
1\end{array}$ & $\begin{array}{l}122.9 \\
9\end{array}$ & $\begin{array}{l}112.9 \\
2\end{array}$ & $\begin{array}{l}117.6 \\
2\end{array}$ & 145.04 & $\begin{array}{l}120.3 \\
1\end{array}$ & $\begin{array}{l}191.3 \\
9\end{array}$ & $\begin{array}{l}132 . \\
67\end{array}$ & $\begin{array}{l}110 \\
.2\end{array}$ & $\begin{array}{l}118 \\
.2\end{array}$ & $\begin{array}{l}134.8 \\
6\end{array}$ & $\begin{array}{l}125.4 \\
4\end{array}$ \\
\hline
\end{tabular}

\section{CONCLUSION}

This study evaluated seasonality in particulates distribution along dumpsites in selected states in the Niger Delta. Findings indicate lower concentration gradient across all dumpsites during the wet season, compared to the dry season, suggesting seasonality in the air quality index. The Health risk assessment showed particulate concentration ranging from slight pollution $(50<\mathrm{HRA} \leq 100)$ to Hazardous $(200<\mathrm{HRA} \leq 250)$. The health risk assessment under both background scenarios showed slight variations. Based on the health risk, sensitive group are at risk if exposed over a prolong period.

\section{REFERENCES}

[1] ACT Government (2018). What is an Air Quality Index? Retrieved October 2018 from http://health.act.gov.au/public-information/public-health/act-air-quality-monitoring/air-quality-index-aqi.

[2] Adejuwon, J.O. (2011). Rainfall seasonality in the Niger Delta Belt, Nigeria.Journal of Geography and Regional Planning, 5(2): 51-60.

[3] Adejuwon, J.O. and Odekunle, T.O. (2006).Variability and the Severity of the "Little Dry Season" in Southwestern Nigeria. American Meteorological Society, 19:483 - 493. 
[4] Akinfolarin, O. M., Boisa, N., and Obunwo, C. C. (2017). Assessment of Particulate Matter-Based Air Quality Index in Port Harcourt, Nigeria. J Environ Anal Chem4: 224. doi:10.4172/2380-2391.1000224.

[5] Angaye, T. C. N., Daokoru-Olukole, C., Abowei, J. F. N. (2018). Environmental Impacts of Municipal Solid Wastes in Yenagoa Metropolis, Bayelsa State, Nigeria. Biotechnol Res. 4(1):17-23.

[6] Angaye, T. C., and Abowei, J. F. N. (2018). Evaluation of suspended particulate matter (SPM) around municipal solid waste dumpsites in Yenagoa metropolis, Nigeria. MOJ Toxicology, 4(2):54-57.

[7] Bhutiani, R., Kulkarni, D. B., Khanna, D. R., and Gautam, A. (2017). Geochemical distribution and environmental risk assessment of heavy metals in groundwater of an industrial area and its surroundings, Haridwar, India. Energy, Ecology and Environment,2(2), 155-167.

[8] Dimari G.A., Hati S.S., Waziri M. and Maitera O.N. (2008). Pollution synergy from particulate matter sources: The Harmattan, fugitive dust and combustion emissions in Maiduguri metropolis, Nigeria. Euro J Sci Res 23 (3), 465-473.

[9] Donwa, P.A., Mgbame, C.O., Utomwen, O.A. (2015). Gas flaring in the oil and gas sector in Nigeria. International Journal of Commerce and Management Research, 1(1): 28-39

[10] Ediagbonya T.F., Ukpebor E.E., Okieimen F.E. and Okungbowa G. E. (2012). Comparative study of TSP, Inhalable Particles and Respirable Particles in Urban and Rural Areas in Niger Delta Region of Nigeria. Greener Journal of Physical Sciences, 2 (3), 089-096.

[11] Efe, S.I. (2008). Spatial distribution of particulate air pollution in Nigerian cities: Implications for human health. J. Environ. Health Res., 7 (2). No page

[12] Ezekwe, C. I., Agbakoba, C., Igbagara, P. W. (2016). Source Gas Emission and Ambient Air quality around the Eneka co-disposal landfill in Port-Harcourt, Nigeria. International Journal of Applied Chemistry and Industrial Sciences, 2(1): $11-23$.

[13] Federal Environmental Protection Agency (FEPA) (1991). National interim Guidelines and Standards for Industrial effluents, Gaseous emissions and Hazardous wastes. Environmental Pollution Control Handbook. Lagos, Nigeria.

[14] Izah S.C., Bassey S.E., and Ohimain E.I. (2018). Ecological risk assessment of heavy metals in cassava mill effluents contaminated soil in a rural community in the Niger Delta Region of Nigeria. Molecular Soil Biology, 9(1): 1-11

[15] Izah S.C., Bassey S.E., and Ohimain E.I. (2017a). Assessment of heavy metal in cassava mill effluent contaminated soil in a rural community in the Niger Delta region of Nigeria. EC Pharmacology and Toxicology, 4(5): 186-201.

[16] Izah S.C., Bassey S.E., and Ohimain E.I. (2017b). Geo-accumulation index, enrichment factor and quantification of contamination of heavy metals in soil receiving cassava mill effluents in a rural community in the Niger Delta region of Nigeria. Molecular Soil Biology, 8(2): 7-20.

[17] Izah S.C., Bassey S.E., and Ohimain E.I. (2017c). Assessment of pollution load indices of heavy metals in cassava mill effluents contaminated soil: a case study of small-scale cassava processing mills in a rural community of the Niger Delta region of Nigeria. Bioscience Methods, 8(1): 1-17.

[18] Ladan, S. I. (2013). Examining Air Pollution and Control Measures in Urban Centers of Nigeria. International Journal of Environmental Engineering and Management, 4(6):621 - 628

[19] Ngele S. O and Onwu F. K (2015). Ambient Air Particulate Matter Levels in Selected Urban Centres of Niger Delta Region, Nigeria. International Research Journal of Environment Sciences, 4(4), 54-63

[20] Ohimain, E.I. and Izah, S.C. (2013). Gaseous emissions from a semi-mechanized oil palm processing mill in Bayelsa state, Nigeria. Continental Journal of Water, Air and Soil Pollution, 4 (1): 15 - 25.

[21] Ohimain, E.I., Izah, S.C. and Abah, S.O. (2013). Air quality impacts of smallholder oil palm processing in Nigeria. Journal of Environmental Protection, 4: 83-98.

[22] Omogbai, B.E. (2010). Rain Days and Their Predictability in South-western Region of Nigeria. J Hum Ecol, 31(3): 185-195

[23] Orogade, SA, Owoade, KO, Hopke PK, Adie DB, Ismail A, Okuofu CA (2016). Source Apportionment of Fine and Coarse Particulate Matter in Industrial Areas of Kaduna, Northern Nigeria. Aerosol and Air Quality Research, 16: 1179-1190.

[24] Oshwofasa, B.O., Anuta, D. E., and Aiyedogbon J. O (2012).Environmental Degredation and Oil Industry Activities in the Niger-Delta Region.African Journal of Scientific Research, 9(1): $444-460$.

[25] Ossai, E.K., Iniaghe, G.O., Osakwe, S.A. and Agbaire, P.A. (1999). Pollution Problems and Environmental Effects of Chemicals, In Ekechi (ed) Reading in General Studies: History and Philosophy of Science, Abraka General Studies Dept. Pub. pp $83-86$. 
[26] Owoade, O.K.; Olise, F.S.; Ogundele, L.T.; Fawole, O.G. and Olaniyi, H.B. (2012). Correlation Between Particulate Matter Concentrations And Meteorological Parameters At A Site In Ile-Ife, Nigeria. Ife Journal of Science, 14(1): 83 -94.

[27] Ubouh, E.A., and Nwawuike, N. (2016).Evaluation of the on-site and off-site ambient air quality (AAQ) at Nekede waste dumpsite, Imo state, Nigeria. International Journal of Environment and Pollution Research, 4(1), 33-38,

[28] Rim-Rukeh, A. (2014). An Assessment of the Contribution of Municipal Solid Waste Dump Sites Fire to Atmospheric Pollution. Open Journal of Air Pollution, 3: 53-60.

[29] Seiyaboh, E.I., Izah, S.C., (2019). Impacts of soil pollution on air quality under Nigerian setting. Journal of Soil and Water Science, 3(1), 45-53.

[30] Weli, V.E. (2014). Atmospheric Concentration of Particulate Pollutants and its Implications for Respiratory Health Hazard Management in Port Harcourt Metropolis, Nigeria. Civil and Environmental Research, 6(5): $11-17$.

Citation: Glory Richard, et.al, " Seasonality in Particulates Distribution from Dumpsites in the Niger Delta Region of Nigeria: A Health Risk Assessment Approach", International Journal of Research in Environmental Science (IJRES), vol. 5, no. 2, pp. 7-15, 2019. Available: DOI: http://dx.doi.org/10.20431/2454-9444.0502002

Copyright:@ 2019 Authors. This is an open-access article distributed under the terms of the Creative Commons Attribution License, which permits unrestricted use, distribution, and reproduction in any medium, provided the original author and source are credited. 